\title{
THE ORGANIZATION OF MADRASAH ALIYAH IN ACEH REFORM ERA
}

\author{
Zainuddin \\ Institut Agama Islam Negeri Langsa \\ Jl. Meurandeh, Langsa Lama, Kota Langsa, Aceh, 24354 \\ e-mail: zainuddin@iainlangsa.ac.id
}

\begin{abstract}
The main problem in this research is the implementation of madrasa aliyah in the reform era in Aceh. In terms of regulation, Madrasa aliyah in Aceh received an equivalent recognition from schools. Whereas when other regions take a lot of positions to prioritize schools, Aceh with its regulatory power should be able to perform more optimally compared to other regions in the archipelago. Seeing this, it is certainly a challenge for Aceh when it must pay attention to madrassas which in regulations in some regions consider it not their authority. The purpose of this study was to determine the conditions and problems of madrasa aliyah, and their policies and impacts. This research is qualitative research with a responsive evaluation approach. After analysis, it was found that the Aceh government still marginalized the Madrasah Aliyah educational institutions, although several regulations allowed Acehnese to do more. This is of course because the Province of Aceh is a special autonomous region that needs special attention based on the legal principle of lex specialis derogat legi generalis.
\end{abstract}

Abstrak: Permasalahan utama dalam penelitian ini adalah implementasi madrasah aliyah pada era reformasi di Aceh. Dari segi regulasi, Madrasah aliyah di Aceh mendapat pengakuan setara dari sekolah. Padahal ketika daerah lain banyak mengambil posisi untuk memprioritaskan sekolah, Aceh dengan kekuatan regulasi yang dimilikinya harus bisa tampil lebih maksimal dibandingkan daerah lain di Nusantara. Melihat hal tersebut tentunya menjadi tantangan tersendiri bagi Aceh ketika harus memperhatikan madrasah yang dalam regulasi di beberapa daerah menganggapnya bukan kewenangannya. Tujuan dari penelitian ini adalah untuk mengetahui kondisi dan permasalahan Madrasah Aliyah serta kebijakan dan dampaknya. Penelitian ini merupakan penelitian kualitatif dengan pendekatan evaluasi responsif. Setelah dilakukan analisis, ditemukan bahwa pemerintah Aceh masih memarjinalkan lembaga pendidikan Madrasah Aliyah, meski ada beberapa regulasi yang memberi peluang bagi masyarakat Aceh untuk berbuat lebih. Hal ini tentunya karena Provinsi Aceh merupakan daerah otonom khusus yang memerlukan perhatian khusus berdasarkan asas hukum lex specialis derogat legi generalis.

Keywords: Madrasah Aliyah, special autonomy, policy, Aceh 


\section{Introduction}

The existence of Madrasah Aliyah as an Islamic educational institution has undergone a transformation. This is evident from the gradual changes in madrasas in a better direction. The implementation of madrasas in the early period of independence was in a marginalized condition. However, the condition of the madrasa will only be integrated after it is passed Law (UU) No. 20 of 2003. After that, the madrasa becomes equivalent to the school, so there is no need for equality tests and the like for madrasas that are not public schools to follow the school curriculum. Thus it can be said that after passing Law No. 20 of 2003 concerning the National Education System has placed education as a systematic whole. ${ }^{1}$

Even so, in reality, madrasa still feels marginalized. Local governments have not yet recognized their authority over madrassas. The funds allocated by the center have not been sufficient to meet the needs of madrasas in running madrasa operations. The implication is madrasa experiencing problems. Funding constraints were an insufficient budget. ${ }^{2}$ Curriculum constraints, lack of improvement in human resources undertaken, in addition to the limited availability of teachers in Madrasah Aliyah. According to data presented by Nur Ahid, the number of teachers in the 2004/2005 school year in Madrasah Aliyah was 90,411 people, while the need for teachers was 114,866 ; there was a shortage of 24,425 teachers. ${ }^{3}$ Likewise, the problem of facilities and infrastructure, the teaching and learning process carried out in Madrasah Aliyah is not supported by adequate facilities and infrastructure.

The results of the study in several regions as a sample still show the government's indifference towards madrasas. Such as Madrasah Aliyah, in Medan City has not received help and attention. ${ }^{4}$ Likewise, the Madrasah Aliyah Pekan Baru has not yet received assistance from the local government. ${ }^{5}$ Many other madrassas have the same fate as the two madrassas. This problem should not have happened, where the equality and equality of madrasas and schools have been legally recognized in Law No. 20 of 2003 concerning the National Education System. But that's what happened; strengthening the status of madrasas through legislation was not supported by the implementation. Ironically, the regional government hopes that madrasas Aliyah education will be of good quality. Conversely, when madrassas hope in local government, they always argue with reasons for rules and legislation so that it appears

${ }^{1}$ Anwar Arifin, Memahami Paradigma Baru Pendidikan Nasional dalam Undang-Undang Sisdiknas (Jakarta: Dirjen Kelembagaan Pendidikan Islam Departemen Agama RI, 2003), p. 6.

${ }^{2}$ Imam Siregar, et.al., Problematika Madrasah Era Otonomi Khusus (Jakarta: Litbang dan Diklat Departemen Agama RI, 2007), p. 27.

${ }^{3}$ Nur Ahid, "Problem Pengelolaan Madrasah Aliyah dan Solusinya," in Islamica, Vol. 4 No. 2, Maret 2010, p. 341.

${ }^{4}$ Siregar, et al., Problematika Madrasah, p. 21-32.

${ }^{5}$ Ibid., p. 32-48. 
the implementation of madrassas in a Muslim minority country. As is the case with madrassas in Singapore, local governments marginalize madrassas in the national education system. ${ }^{6}$

In contrast to the conditions of Madrasah Aliyah in Aceh, the implementation of special autonomy provides an opportunity for Aceh to determine its regional management accompanied by giving freedom to Aceh with the authority of regional legislation in the form of the Aceh Qanun. Thus, Aceh can express and create differently from other regions regarding the delivery of madrasa education, including the implementation of Madrasa Aliyah. Rules and regulations are formulated to look like the madrasa position with the school. In the Aceh education strategic plan, it was stated that the authority to manage madrassas was under the authority of the city district, but funding was still sought from the Ministry of Religion. ${ }^{7}$ Likewise in the qanun, madrasa side by side with schools in receiving funds from the Aceh government.

The problem is, how is the local government's policy towards Madrasah Aliyah in Aceh, and how does the Aceh government implement the policy? Whereas legally, Madrasah Aliyah is a vertical institution which is still the authority of the central government. In-Law No. 11 of 2006 clearly stated that religion became part of the authority and responsibility of the central government. Even the Minister of the Interior once banned the regions from allocating the regional budget for religious education; considered religious not part of decentralization through Circular Letter (SE) number 903/2429/SJ dated September 21, 2005.

Although the rules do not allow in the implementation of Law No. 11 of 2006 concerning the Government of Aceh, the position of madrasas is equivalent to schools. The mention of madrasas and schools always hand in hand shows that madrasas have the same rights as schools. The problem is, how to implement the policy? This is a problem regarding the condition of Madrasah Aliyah in Aceh that needs to be studied. The selection of Madrasah Aliyah in Aceh was the focus of the study because the position of Madrasah Aliyah was different from madrasas at the Ibtidaiyah and Tsanawiyah levels. In terms of regulation, Madrasah Ibtidaiyah and Madrasah Tsanawiyah have been mentioned in the Law on Aceh Government Number 11 of 2006 and the Aceh Education Strategic Plan for 2007-2012. In contrast to Madrasah Aliyah, this is only mentioned in Qanun Number 5 of 2008. In this case, Madrasah Aliyah is equivalent to secondary school. The existence of this uncertainty both juridical and reality makes Madrasah Aliyah interesting to study.

Based on the description of Madrasah Aliyah's position in the implementation of special autonomy in the reform era, there are several important questions raised. How was the

${ }^{6}$ Charlene Tan, “Contesting Reform: Bernstein's Pedagogic Device and Madrasah Education in Singapore", in Journal of Curriculum Studies, Vol. 42, No. 2, 2010, p. 68.

${ }^{7}$ Darwis A. Sulaiman, et al. (ed.), Rencana Strategis (Renstra) Pendidikan Naggroe Aceh Darussalam 2007-2012 (Banda Aceh: Guruminda, 2007), p. 10. 
implementation of Madrasah Aliyah in Aceh in the reform era, and what problems did it face? What is the policy for the implementation of Madrasah Aliyah in Aceh in the Reformation era? What is the impact of government policies on the implementation of Madrasah in the reform era Aceh?

\section{Theoretical Framework}

Madrasas in various dynamics are always accompanied by various policies. Thus, the education that is held cannot be separated from policies. Therefore, it is appropriate to see the implementation of education using the policy cycle theory. Werner Jann and Kai Wegric describe the steps of the policy cycle, namely Agenda Setting, Policy Formulation, Policy Implementation, Policy Evaluation, Policy Change, and Policy Termination. ${ }^{8}$

At the stage of agenda-setting, policymakers will gather public issues. Then analyzed and followed by the formulation of policymaking. The next cycle is to implement the policy in the community, and followed by evaluating. According to Grindle, as quoted by Tilaar and Riant Nugroho, the success of a policy is largely determined by the degree of its implementation. ${ }^{9}$ In its implementation, the policy is the basic idea that is transformed; the policy implementation is carried out. To measure the achievement of policy, attention needs to be paid to the aspects of its implementation. By analyzing the results of evaluations, adjustments, or changes are made to improve the policy. The final step of the policymaking cycle is to end the policy because the objectives have been achieved. The operational of the theory in this study is internalized in the answers to the problems that have been raised.

\section{Methodology}

This study uses qualitative research, namely research that aims to describe the integrity of a problem or a problem that exists in Madrasah Aliyah. ${ }^{10}$ The data that has been described is analyzed to find the government's partiality and justice towards the implementation of Aliyah Madrasah in Aceh by using descriptive and evaluative that is in accordance with the policy. ${ }^{11}$ The research approach used is the responsive evaluation approach. Madaus

\footnotetext{
${ }^{8}$ Werner Jann and Kai Wegrich, Handbook of Public Policy Analisys: Theory, Politic, and Methods (New York: CRC Press Taylor And Francis Group, 2007), p. 43-62.

${ }^{9}$ H.A.R. Tilaar and Riant Nugroho, Kebijakan Pendidikan: Pengantar untuk Memahami Kebijakan Pendidikan dan Kebijakan Pendidikan sebagai Kebijakan Publik (Yogyakarta: Pustaka Pelajar, 2009), p. 220.

${ }^{10}$ Parsudi Suparlan, Pengantar Metodologi Penelitian Kualitatif (Semarang: Fakultas Tarbiyah, Majalah Media edisi 14 tahun 1993), p. 19.

${ }^{11}$ H.A.R. Tilaar, Paradigma Baru Pendidikan Nasional (Jakarta: Rineka Cipta, 2004), p. 242.
} 
suggested that this approach was used to evaluate programs for achieving results from implementing policies. ${ }^{12}$

This research was conducted in Aceh with purposively selected areas as follows: Seumeulu State Madrasah Aliyah, Banda Aceh Model State Madrasah, North Aceh State Madrasah Aliyah, North Aceh Private Madrasah Aliyah, Takengon State Madrasah Aliyah, Takengon Private Madrasah Aliyah, Aceh Tamiang State Madrasah Aliyah, and Aceh Tamiang Private Madrasah Aliyah. In addition to the data, data is also used in the form of legislation, government regulations, Ministerial Regulations, Decrees of the DirectorGeneral, Aceh Qanun, and Education Strategic Plan in Aceh from 2007 to 2012, and the Helsinki MoU. Educational stakeholders in Aceh, namely the Head of the Aceh Provincial Office of the Ministry of Religion, the Aceh Regional Representative Council (DPRA), the Education Office, Bappeda, the Educational Consultative Council (MPD).

To get data from the sources that have been mentioned carried out three ways, namely observation, ${ }^{13}$ interviews, and documentation. The observation was carried out by observing the condition of the madrasa, both from the physical condition, the environment, and the available infrastructure. ${ }^{14}$ Interviews are conducted in an unstructured and open manner. The statements that will be asked are not bound even though several questions have been prepared. ${ }^{15}$ While the general interview is the interview conducted with the knowledge of the person being interviewed. In other words, the interview is conducted openly; the interviewer knows that he is being interviewed. ${ }^{16}$ While the documentation is Law, PP, Regulation of the Minister of Religion, UUPA, Qanun, and Aceh Education Strategic Plan.

For data analysis, this study follows the paradigm of qualitative methods ${ }^{17}$ by Huberman and Miles, namely data reduction, data presentation, and drawing conclusions or verification. This process is carried out before data collection, precisely when determining the research design; when collecting preliminary data and preliminary analysis data; and after the final data collection stage. ${ }^{18}$ Data analysis was performed based on the interaction of the

${ }^{12}$ Daniel L. Stufflebian, et al., Evaluation Models Viewpoints on Educational and Human Service Evaluation Second Edition (London: Kluwer Academic Publishers, 2000), p. 303.

${ }^{13}$ Hermawan Warsito, Pengantar Metodelogi Penelitian (Jakarta: Gramedia Pustaka Utama, 1995), p. 22.

${ }^{14}$ Lexy J. Moleong, Metodologi Penelitian Kualitatif (Bandung: Remaja Rosdakarya, 2012), p. 126.

${ }^{15}$ Basrowi dan Suwandi, Memahami Penelitian Kualitatif (Jakarta: Rineka Cipta, 2008), p. 130.

${ }^{16}$ Ibid, p. 129.

${ }^{17}$ John W. Creswell, Research Design Qualitative and Quantitative Approaches, translate by Nur Khabibah (Jakarta: KIK Press, 2002), p. 5-6.

${ }^{18}$ A. Michael Huberman dan Mattew B. Milles, "Manajememen Data dan Metode Analisis", in Norman K. Denzim dan Yvonna S. Lincoln, Handbook of Qualitative Research, tr. Dariyanto, et al. (Yogyakarta: Pustaka Pelajar, 2009), p. 592. 
four main components. Data analysis uses the interactive method of the Huberman and Miles ${ }^{19}$ model with the following stages. First, record all the findings of the phenomenon in the field. Second, review the records of results from the field and separate important and non-important data. This work is repeated to examine the possibility of misclassification. Third, describe data that has been clarified for further analysis by taking into account the focus and purpose of the research. Fourth, make a final analysis for writing research reports and conclusions. To determine the validity of the data, several steps were tested for the validity of the data on qualitative data, ${ }^{20}$ namely credibility (degree of trust), transferability (dependability), dependability (dependency), and confirmability (certainty criteria).

\section{Condition and Problems of Madrasah Aliyah in Aceh}

\section{Condition of Aliyah Madrasa in Aceh}

The implementation of madrasas in Aceh is increasing. From 2008 to 2016, madrasas have reached 237 from the previous figure of 186 madrassas or an increase of $60 \% .{ }^{21}$ of the total 237, 169 (71\%) are public, while the remaining $68(28.7 \%)$ are still private. The quality also shows an increasing number. Based on Islamic Education emis data, it shows that the number of accredited Madrasas Aliyah is 75\%, with details of accredited A as much as 50 (21\%), accredited B as much as 83 (35\%), accredited C as much as 45 (19\%), while as many as not accredited 59 (25\%).

Madrasas that achieved the most A accreditation were around 33 (49\%) State Madrasah Aliyah (MAN), while only 17 (10\%) Private Madrasah Aliyah (MAS). Whereas accreditation $\mathrm{B}, \mathrm{C}$, and not accredited by MAS is more dominant than MAN. However, if it is considered as a whole and compared to previous periods, the implementation of Aliyah Madrasah in Aceh has shown good improvement, both in terms of quantity and quality.

In terms of funding, the administration of Madrasah Aliyah in Aceh is the responsibility of the central government. There are several madrassas also get funding from other funds, such as local governments, communities, and madrasa personal assets. Central government funding in each year experiences instability, sometimes it goes up, but at a certain time, the amount of the budget decreases. Likewise with BOS funds, even though it has been stated that the total cost/fee received Rp. 1,200,000/year, but admission at the madrasa level is not stable. Like Madrasah Aliyah Bayu Private, BOS costs received in 2016 were only Rp. 1,000,000/student/year because the funds available at the Ministry of Religion are insufficient due to budget cuts by the Central Government. Likewise, the acknowledgment of the head of the Lhoksukon State Madrasah Aliyah, BOS funds budgeted in 2016 was

\footnotetext{
${ }^{19}$ Ibid.

${ }^{20}$ Moleong, Metode Penelitian, p. 324.

${ }^{21}$ Data from the Aceh Province Bureau of Statistics 2016.
} 
cut, so that each student only received Rp. 1,080,000. Of course, this will affect all madrassas in Indonesia, including Aceh.

In contrast to the central government, local government funding is not binding. However, it is not inevitable that certain madrassas get regular budgets from the local government. Based on this, there are three conditions for funding Madrasah Aliyah in Aceh from the regional government in Aceh. First, madrassas get regular funding; Second, madrasas that sometimes get funding; third, madrasas that have never received funding from the Aceh government. A first group is several Madrasah Aliyah who is considered equivalent to the school. In this case, the local government allocates a budget for Madrasah Aliyah the same as schools. For example, MAS Sungai Iyu Aceh Tamiang always routinely gets budget allocations from the government of Aceh Tamiang Regency. In this case, it appears that the attention given to the MAS Sungai Iyu by the Aceh Tamiang government is not purely the government's concern for the madrasa, but there is an emotional connection between the foundation and the government in charge.

The second group is madrassa that doesn't routinely get funding. Like Seumeulu State Madrasah Aliyah, which receives funding from the local government, but not every fiscal year, depends on the lobbying relationship established by the madrasa. The third group is madrasas that do not get funding from local governments. Among them is Private Madrasah Aliyah Bayu North Aceh. Its implementation never received financial assistance from local governments. Whereas the existence of madrasa is very alarming and the students are educated by poor families. Let alone to pay for school, even buying uniforms is not able to, so the madrasa provides uniforms for students. ${ }^{22}$

Likewise, MAN 1 Meulaboh, the budget allocation from the central government is the only source received by madrasas. All madrasa needs only rely on DIPA and the BOS program. To anticipate budget shortages, parties must limit their activities and programs. ${ }^{23}$ The same condition is also recognized by several other madrassas, such as the MAN Model Banda Aceh. Although its existence as a model madrasa with programs and excellence that has been achieved has raised the name of Aceh, the funding has never been received from the Aceh regional government or the Banda Aceh Municipality. ${ }^{24}$

The community funding in the form of funds comes from the committee and through student tuition fees. Funding from the committee is income from Madrasah Aliyah through the committee mediator with the community, either as student guardians or not. This funding is voluntary. Usually, this budget is devoted to covering needs not available in the

${ }^{22}$ The Head Master of Bayu Private Madrasah Aliyah, interview in Bayu Lhoksukon, North Aceh Regency on December 28, 2016.

${ }^{23}$ The Head Master of MAN 1 Meulaboh, interview in Meulaboh, West Aceh, January 10, 2017.

${ }^{24}$ Emis Data of Islamic Education Ministry in 2016. 
Dipa or BOS Funds. As MAN Takengon used the funds sourced from the efforts of the committee to pay the salaries of service teachers. Likewise the other madrassas in Aceh. But in this case, it appears that madrasa financing is strongly supported by the conditions of the local community, if the economy is poor, the effort to find funds through the committee is very difficult. This is as seen in MAS Bayu cannot expect to fund from the committee due to the low economic conditions of the people. ${ }^{25}$ Besides, public funding for madrasas can also be in the form of tuition fees. But this pattern is not practiced by all madrassas, only certain madrassas are "determined" meanwhile some specific MANs do. However, some madrassas don't dare to do it. Like MAN 1 Meulaboh who no longer takes tuition fees from students even though the available budget is not sufficient.

Apart from the funding sources that have been mentioned, Madrasah Aliyah also gets funding from its own business. This funding comes from the assets of the madrasa itself. This condition is commonly seen in madrasas that are managed under pesantren. Private Madrasah Aliyah Darul Mukhlisin Takengon implements a funding system from the results of his efforts. The Aliyah Madrasah gets funding from its assets. This fund is also used to supply school operations that are less than BOS funds and other assistance.

The condition of the Madrasah Aliyah curriculum in Aceh since the beginning of the reform period until now refers to the national curriculum and refers to national standards. If there are dynamics and changes in the course of the curriculum in Indonesia, Madrasah Aliyah can adjust to it while maintaining its Islamic characteristics. ${ }^{26}$ At the time of this study Madrasah Aliyah in Aceh used two curriculum models, some used the 2013 curriculum (K13), and some used the KTSP curriculum. Such as the MAN Model Banda Aceh is one of those that use the 2013 curriculum. Likewise, MAN Kuala Simpang uses Curriculum $\mathrm{K} 13$ in the learning process. In addition to the two MANs, another Aliyah Madrasah that uses K13 is MAN 1 Takengon.

Whereas Madrasas Aliyah who still use the KTSP curriculum are Bayu Private Madrasah, MAS Darul Mukhlisisn Takengon, MAS Aceh Tamiang Sungai Iyu, and MAN Seumeulu. Although some of these madrassas have not used the 2013 curriculum, for certain subjects, such as Arabic and Islamic Religious Education, these madrassas have used the 2013 curriculum. In the future, these madrasas are being prepared to use the 2013 curriculum so that in the future all the above madrasa already uses the 2013 curriculum, although its implementation is still gradual.

In addition to the national curriculum, Madrasah Aliyah also includes local content as a form of regional characteristics, namely the implementation of Islamic law and regional

${ }^{25}$ The Head Master of Bayu Private Madrasah Aliyah, interview in Bayu Lhoksukon, North Aceh Regency, December 28, 2016.

${ }^{26}$ Yoga Anjas Pratama, "The integration of Madrasah Education in the National Education System: Study of Madrasah Education Policy in Indonesia," in Al-Tadzkiyyah: Journal of Islamic Education, Vol. 10 No. 1, 2019, p. 98. 
languages. Both forms of local content are applied in every madrasa. Implementation of Islamic law is usually filled with reading the Koran, memorizing the Qur'an, and other religious activities. Local languages such as Acehnese, Gayo, and other regions used it as their regional languages. MAN Takengon included Gayo in local content and added guidance in the Qur'an. The Banda Aceh Model MAN makes the Qur'anic catfish, calligraphy, and ICT as local content. MAN 1 Meulaboh makes the Qur'anic hafidh as local content. Likewise with Madrasah Aliyah in other areas.

The human resources in question are teachers at Madrasah Aliyah. Based on Islamic Education Emis data, there are 5247 Madrasah Aliyah teachers in Aceh. Teachers with the status of civil servants were 1869 people (36\%) and non-civil servant teachers were 3378 (64\%). Also, it was seen from the level of education. Based on Islamic Education emis data, the number of teachers graduating from one or more teachers is 5025 (96\%), and there are not yet 222 people (4\%). ${ }^{27}$ Judging from the level of education, the quality of teachers for Madrasah Aliyah has been said to be good, because on average madrasas prioritize teachers who have completed S1. As informed by the Head of MAN 1 Meulaboh that the qualifications of teacher education in MAN are all have taken Strata One (S1) ${ }^{28}$ Besides, the number of these teachers taught and mentored as many as 44668 students spread across 237 Aliyah Madrasah Education institutions.

The facilities and infrastructure of Madrasah Aliyah in Aceh in the reform era can be seen from the availability of classrooms, computer laboratories, and physics laboratories. The number of classrooms currently owned by Madrasah Aliyah is 1242 with good rooms, 423 are damaged, and 157 rooms are heavily damaged. While the computer laboratory totals 90 computer rooms. The details, as many as 55 goods, damaged 17, and heavily damaged 18. While the physics laboratory numbered 48 pieces, with the details, 29 good, 11 damaged, and 8 heavily damaged. ${ }^{29}$ The number of facilities and infrastructure has included public and private madrassas. If there are do not yet have the facilities and infrastructure.

\section{Problems in the Implementation of Madrasah Aliyah in Aceh in the Reformation Era}

From the description of the condition of Madrasah Aliyah in Aceh, the reform era shows problems in Madrasah Aliyah, including funding, curriculum, human resources, and infrastructure. The problem with the funding is that the funds allocated by the central government are not sufficient. Hoping from other sources will be constrained by authority and regulation. The implication is that the infrastructure and supra-structure of Madrasah

${ }^{27}$ Emis Data of Islamic Education in 2016.

${ }^{28}$ The Head Master of MAN 1 Meulaboh, interview in Meulaboh, West Aceh, January 10, 2017.

${ }^{29}$ Emis Data of Islamic Education in 2016. 
Aliyah show very poor conditions. Madrasa runs improperly without adequate facilities and some madrassas have to eliminate activities due to financial constraints. For example, the condition of the MAN Model Banda Aceh had to abandon several important activities due to funding constraints, even though these activities could be improving the quality of education in the Madrasah Aliyah. ${ }^{30}$ Likewise, MAN 1 Meulaboh must leave important activities because of funding. ${ }^{31}$ This condition is exacerbated by the prohibition of quoting the guardians of Madrasah Aliyah students.

The most difficult conditions related to funding are seen in MAS Bayu. This madrasa only relies on BOS funds from the central government in small amounts. The condition of the madrasa for one teacher's room is divided into the room of the Madrasa Head, teacher, administration, and room for one bookshelf which only contains 10 example books. Also, the madrasa environment is located in the rice fields of the community without a fence that limits the madrasa grounds. Likewise, related to the completeness of learning, such as chalk, and learning books must spend their own money to buy it. ${ }^{32}$

In contrast to funding, so far the curriculum in Aceh does not reveal significant problems. The Madrasah Aliyahs only carry out the general national standard curriculum, adding a few local contents. This is acknowledged by all Madrasah Aliyah in Aceh. For example, the MAN Model in Banda Aceh uses the national curriculum as a curriculum learned in madrasas. Likewise, other madrassas do the same thing as MAN Model Banda Aceh.

But the problem is, if two directions of subjects between local content and madrasa lessons are maintained, it will have an impact on the allocation of hours for each subject. ${ }^{33}$ If in this condition it is certain that the subject of local content will be lost in the school curriculum, including Madrasah Aliyah. Because it is considered not too significant when compared with madrasa subjects (national standards) ${ }^{34}$ In the case of the existence of local content in the madrasa curriculum becomes an amplifier of the madrasa curriculum system. ${ }^{35}$

Regarding human resources, from the data obtained, the problem of educators in the Madrasah Aliyah environment takes two forms, namely quantity, and quality. The quantity

30 The Head Master of MAN Model Banda Aceh, interview in Banda Aceh, Desember 28, 2016.

${ }^{31}$ The Head Master of MAN 1 Meulaboh, interview in Meulaboh, West Aceh, January 10, 2017.

${ }^{32}$ Bayu Private Madrasah Aliyah, observation in Bayu, North Aceh Regency, December 28, 2016.

${ }^{33}$ Tahar, the Head of Curriculum for the Regional Office of the Religious Ministry Affairs in Aceh Province, interview in Banda Aceh, December 28, 2016.

${ }^{34}$ Daud Yahya, "Position of Madrasas in the National Education System in the Reform Era" in Jurnal Khazanah, Vol. XII, No. 01 2014, p. 84.

${ }^{35}$ Ali Imron, "Strengthening Moderate Islam through the Learning Method of Democracy in Madrasah Ibtidaiyah," in Jurnal Edukasia Islamika: Jurnal Pendidikan Islam, Vol. 3 No. 1, 2018, p. $1-17$. 
problem is related to the number of teachers not meeting the needs of study groups in madrasas. The number of teachers available in Madrasah Aliyah in Aceh is 5247 people. Teaching in MAN is 2411 (45\%), while MAS is 2836 (54\%) teachers. When compared with the number of Madrasah Aliyah it is certainly not sufficient. MAN 1 Meulaboh has 926 students divided into 26 study groups. Based on this ratio, there should be 60 teachers available, but only 30 teachers or $50 \%$ of the total teachers needed.

In quality, the teachers who teach in Madrasah Aliyah are outside their fields or the teacher who teaches the different subjects. PAI teachers teach history or vice versa. The result is less than the maximum in learning, especially those not in their fields. MAN 1 Takengon claimed to have enough teachers in the teaching and learning process, but for certain lessons must use the services of teacher salaries, sometimes his knowledge with subjects that teach is not appropriate. For MAN 1 Takengon managers this effort must be made to avoid teacher shortages. ${ }^{36}$ Likewise, the information provided by the Head of MAN Kuala Simpang Aceh Tamiang that in the madrasa have many teachers, but the majority of available teachers are Islamic Religious Education teachers, while general teachers, such as mathematics teachers, are not yet available.

Regarding facilities and infrastructure, the availability of facilities and infrastructure in Madrasah Aliyah has not been sufficient to meet the needs, both seen in the availability of study rooms, computer laboratories, and physics laboratories. The ratio of classrooms available is 1822, with details, 1242, good, 423 damaged, and 157 heavily damaged. These conditions indicate the number of classrooms provided that the study group is insufficient.

The condition of MAN Subulussalam ${ }^{37}$ which has 290 students is divided into 8 groups. Each class consists of 32 students. According to information from the Head of Subulussalam State Madrasah Aliyah, the two classrooms used for the teaching and learning process were no longer feasible, the room was rather dark and leaky, but because the number of students continued to increase while the classrooms were insufficient, we were forced to use the space with little doing renovations. MAS Bayu does not have Meubilers in the class so other classes must be bulkheaded with plywood. ${ }^{38}$ MAN Aceh Tamiang, the ratio of the number of class students has passed the effective limit because the number of students per student is 35 people, the effective number should be 15: 1 in accordance with Government Regulation (PP) No. 74 of 2008 and a maximum limit of 32 students. If seen from the number of students in each of the three Madrasah Aliyah classes, the learning that was applied to the three madrasas was not effective. The determination of the study

${ }^{36}$ The Head Master of MAN 1 Takengon, interview in Takengon Aceh District, January 9, 2017.

${ }^{37}$ Emis Pendis data 2016.

${ }^{38}$ Bayu private Madrasah Aliyah, observation in Bayu, North Aceh Regency, December 28, 2016. 
group does not have to be beyond the standard of the study group for SMA/MA. In the Permendiknas it is stated that the maximum limit for study groups in SMA/MA is 32 people. $^{39}$

Apart from classrooms, Madrasah Aliyah is still lacking in computer laboratories, even for certain madrasas that are not available. In total there are 90 computer laboratories available in MA, with details of 55 (17\%) good, 17 (19\%) damaged, and 18 (20\%) severely damaged. The comparison of the number of madrasas is 237 then only $182(77 \%)$ madrassas have a computer laboratory, and even than including the damaged and heavily damaged. Also, the problem of madrasas is in the ownership of physics laboratories. When compared to the number of madrasas with the availability of physics laboratories, only $20 \%$ have them, while others do not yet have them. Whereas the learning process in madrassas organizes natural science majors, of course, a physical laboratory is a necessity.

\section{Government Policy towards Madrasah Aliyah in Aceh}

Examining the policy regarding Madrasah Aliyah, of course, the role of the central government and regional governments is the main source that must be elaborated. The central government is the authorized and responsible party in organizing Madrasah Aliyah. The local government is an observer of the implementation of madrassas.

\section{Central Government Policy}

The central government policy towards Madrasah Aliyah has been started since the adoption of Law Number 22 the Year 1999 concerning Special Autonomy. Specifically, the Law does not regulate the administration of Madrasah Aliyah, but the transfer of tasks and the authority to provide education is given to the regional government. However, after Law No. 22 of 1999, the conditions of madrasas and schools were different. Madrasas become a centralistic part, while schools are decentralized. The transfer of authority in the administration of regional finance is ambiguous for Madrasah Aliyah. On the one hand, madrasas are understood as educational institutions, on the other hand, they are part of religious institutions. This difference creates a polemic in the administration of madrassas. As a religious institution, the position of the madrasa becomes a vertical institution that is not autonomies. But by the organizer, the madrasa agreed to say as an educational institution so that the madrasa did not have the same rights as an educational institution.

This condition changed after the implementation of Law Number 20 the Year 2003 concerning the National Education System. This law has placed madrassas in an equal

\footnotetext{
${ }^{39}$ National Education Standards Agency, Regulation of the Minister of National Education of the Republic of Indonesia Number 41 of 2007 concerning Process Standards for Elementary Secondary Education Units (Jakarta: BNSP, 2007).
} 
position in national education. Madrasas and schools are seen as equal educational institutions. There is no longer any differentiation of educational institutions implemented by certain ministries, all of which refer to national education systems and standards. So much the government's attention to madrassas in Law no. 22 of 2003 so that the Act becomes the basis for a paradigm shift in the delivery of education in Madrasas, both in terms of funding, curriculum, human resources, and infrastructure.

In the aspect of funding explained in Chapter XIII article 46 paragraph (1) that education funding is a shared responsibility among the central government, regional governments, and the community. In other words, the role of the private sector and the community in education funding will determine this policy and make education funding no longer centered on the state, which originally comes from state revenues such as taxes or other state businesses. Educational funding can also be sourced from private parties such as grant funds, foreign loans, or bilateral cooperation with other countries. Furthermore, in article 46 paragraph (2) the central and regional governments are required to provide a budget, as stipulated in the 1945 Constitution article 31 paragraph (4) which legitimizes article 49 paragraph (1) which sets out the allocation of education funds in addition to teacher salaries and the cost of official education is at least $20 \%$ both in the state budget (APBN) and the regional budget (APBD).

As for the curriculum aspects of the act, education held in madrasas has the same status as schools. Madrasas and schools are together to achieve national education goals. The existence of this demand for equality, the Ministry of Religion must formulate a curriculum that reflects national standards, but does not eliminate the Islamic style of authenticity. The curriculum framework used refers to government regulations. The attitude taken by the Ministry of Religion in this regard is to adjust to the general curriculum which at that time was based on competence (KBK) while maintaining its Islamic characteristics. After two years of KBK being implemented as a form of Madrasah Aliyah curriculum, in 2006 the government replaced it with KTSP (Education Unit Level Curriculum). KTSP is made based on Law No. 20 of 2003 article 36 paragraphs 1 and 2, PP. No. 19 of 2005 concerning National Education Standards in Chapter IV articles 16 and 17, KTSP and Permendiknas No. 22, 23, 24 of 2006 and also Permenag No. 2 of $2008 .{ }^{40}$ In 2013, the madrasa and school curriculums changed back to the 2013 curriculum. The juridical foundation for the 2013 curriculum was Law No. 20 of 2003, Law No. 17 and 19 of 2005, and PP No. 32 of 2005 concerning Amendments to PP No. 19 of 2005 concerning National Education Standards. This juridical basis has underlain the birth of Permendikbud No. 69 of $2013 .{ }^{41}$ To implement

${ }^{40}$ Heri Gunawan, Curriculum and Learning Islamic Religious Education (Bandung: Alfabeta, 2013), p. 63.

${ }^{41}$ Permendikbud No. 692013 concerning Basic Framework and Curriculum Structure of Senior High School/Madarasah Aliyah,p. 6. 
the 2013 curriculum on madrassas, the Ministry of Religion issued Permenag No. 912 of 2013 concerning technical curriculum implementation and content standards.

Also, the government's serious efforts are seen in improving the quality of Human Resources (HR). After being passed Law No. 20 of 2003 concerning the National Education System which shows the political will of the government to prosper, provide guidance, and facilitate the need for educators and education staff consistently. ${ }^{42}$ One of the government policies governing the standardization of a teacher is Law No. 14 of 2005 concerning teachers and lecturers. In article 1 paragraph (1) and (2) it is explained that the teacher is a professional educator with the main task of educating, teaching, guiding, directing, training, evaluating, and evaluating students in early childhood education through formal education, basic education, and secondary education.

The government policy on facilities and infrastructure is to facilitate the implementation of the learning process in schools. In accordance with PP No. 19 of 2005 in Chapter VII article 42 which states that, educational equipment, educational media, books, and other learning resources, consumables, and other equipment needed to support an orderly and continuous learning process. Likewise with Law No. 20 of 2003 which requires every educational institution both formal and non-formal to meet the needs of facilities and infrastructure in developing the physical, intelligence, intellectual, social, emotional, and student's potential. ${ }^{43}$ In Government Regulation No. 24 of 2007, the facilities and infrastructure in question are classrooms, library rooms, laboratories for physics, chemistry, computers and languages, leadership rooms, teacher rooms, TU rooms, places of worship, classrooms, UKS rooms, student organization rooms, latrines, warehouses, circulation room, and playground/sports.

This is in line with Minister of Religion Regulation No. 90 of 2013 concerning the implementation of education article 40 paragraphs 2 . This rule emphasizes that every education unit must have infrastructure which includes land, classrooms, madrasa leadership rooms, teaching space, administrative space, library room, laboratory room, power installation and services, a place to exercise, a place of worship, a place to play, and other spaces/places needed to support an organized and continuous learning process. In article 3, MAK is required to have production unit space and must comply with the SNP. ${ }^{44}$

\section{Local Government Policy}

The Aceh government's policy towards madrassas is seen in the rules on the delivery of education in Aceh. Moreover, the position of Aceh, compared to other regions, has specificity in managing its region. This condition began since a mutual agreement between the

${ }^{42}$ UU No. 20 of 2003 concerning SISDIKNAS CHAPTER XI in articles 39-44.

${ }^{43}$ See Law No. 20 of 2003 concerning SISDIKNAS in CHAPTER XII Articles 45 (1) and (2).

${ }^{44}$ Permenag No. 90 of 2007 Madrasah Education, article 40. 
Indonesian government and the Free Aceh Movement, better known as the Helsinki MoU. In the memorandum, various sectors under the authority of the Aceh government are regulated, including education, in addition to controlling $70 \%$ of all hydrocarbon reserves and other existing and future natural resources in Aceh and the territorial sea around Aceh. ${ }^{45}$

All policies in the Helsinki MoU Memorandum that were mutually agreed upon were then promulgated in Law Number 11 of 2006 concerning the Government of Aceh, or better known as the "LoGA". This law regulates all forms stipulated in the Helsinki MoU, including the administration of education. Article 182 clause 3 states that education is entitled to get $30 \%$ of revenue sharing and natural gas. Then in article 193 paragraph 1 , it is stated that the budget for education funding is $20 \%$ of the Aceh Revenue Expenditure Budget (APBA) and the Regency/City Revenue Expenditure Budget (APBK). ${ }^{46}$

Explicitly, the LoGA does not mention Madrasah Aliyah. However, the articles that talk about education in the law become the forerunner to the determination of Madrasah Aliyah in Aceh which was discussed in the Aceh education strategic plan for 2007-2012. As explained in the 2007-2012 Nanggroe Aceh Darussalam Education Strategic Plan (Renstra) that the preparation of this Strategic Plan is also a step towards ensuring funding for SD/ MI, SMP/MTs, and SMA/MA. ${ }^{47}$ An important part of guaranteeing strategic planning is implementing Aceh education without discrimination and compartmentalizing certain institutions. All education is considered equal in the authority of the Aceh government. ${ }^{48}$

The position of the madrasa became even clearer after the passing of Qanun Number 5 of 2008 concerning the administration of education in Aceh. Then it was replaced with Qanun Number 11 of 2014 and renewed with Qanun Number 9 of 2015. All of these qanuns regulate the holding of education in Aceh, including madrassas because in the Qanun between madrasas and schools are always called hand in hand. Thus, every policy contained in the Qanun for schools certainly applies to madrasas. This can be seen in funding, curriculum, human resources, and facilities and infrastructure.

Regarding funding, in Qanun No. 5/2008 it is stated that the provincial and district/ city governments must prioritize a $20 \%$ budget from the APBA and APBK. ${ }^{49}$ Article 44 also states: "At least 30\% (thirty percent) of the revenue of the Government of Aceh originating from the additional oil and gas Production Sharing Fund referred to in paragraph (1) shall be allocated to finance education in Aceh. All budgets set for school/madrasah expenditure. ${ }^{50}$

${ }^{45} \mathrm{MoU}$ Helsinky, Memorandum of Understanding between the Government of the Republic of Indonesia and the Free Aceh Movement, p. 1-4.

${ }^{46}$ Law Number 11 of 2006 concerning Aceh Governance.

${ }^{47}$ Sulaiman, et al. (ed.), The strategic plan, p. 5.

${ }^{48} \mathrm{Ibid}$.

${ }^{49}$ In article 43 paragraph 2.

${ }^{50}$ Article 46. 
This condition is still the same in Qanun Number 11 the Year 2014 and the amendment to Qanun Number 9 the Year 2015.

As for the curriculum in Qanun Number 5 the Year 2008 article 35 paragraph 1-7 is mentioned: The curriculum used in each type and level of education is in accordance with national content standards and local content implemented in Islam. Qanun Number 11 the Year 2014 also requires madrassas, including Madrasah Aliyah, to be subject to regulated subjects, including local content which is carried out Islamic. The difference between this qanun and the previous one is the emphasis on creating a new curriculum that displays the Achan criteria. Likewise in Qanun Number 9 of 2015. In this Qanun many regulate the standard of education in Aceh by referring to Islamic competence, especially related to the preparation of the Islamic curriculum.

Regarding educators, in Qanun Number 5 the Year 2008, it was stated that educators and education staff were positioned equally between schools and Madrasah Aliyah. Then in Qanun No. 11 of 2014, also regulates human resources (HR). In Qanun Number 9 of 2015, relating to educators, plus several other articles to support the aforementioned articles. There are important things to be added to this qanun regarding educators, namely the requirements for education not to abuse Narcotics, Alcohol, Psykotropika, other Addictive Substances (NAPZA), and have competence in teaching at primary and secondary levels. Whereas in Qanun Number 5 of 2008 in 41 more detailed regulates the responsibilities of the Government of Aceh in the procurement and maintenance of educational facilities and infrastructure. Likewise with the qanuns thereafter. Regarding the implementation of Madrasah Aliyah, there are no visible limitations as a differentiator between madrasas and schools.

After the enactment of Qanun No. 11 of 2014, this condition has changed slightly, in some cases, madrasas must be distinguished from schools. If in the previous Qanun, the regional government allowed madrasas, but in Qanun Number 11 of 2014, the administration of education was also still given an opportunity, but was bound and limited by education within the regional authority. ${ }^{51}$ This will certainly narrow the opportunity for Madrasah Aliyah to be equal to schools in the authority and responsibilities of local governments. The position of madrasas is positioned the same as other vertical institutions that receive grant assistance from the Aceh Revenue Expenditure Budget (APBA).

Thus, from the policies that have been issued in the LoGA, the Qanun on education, the condition of educational institutions in Aceh is not marginalized. Madrasas and schools are considered the same in rules and legislation. Since Qanun Number 5 the Year 2008 appeared, was replaced by Qanun Number 11 the Year 2014, and the latest change

${ }^{51}$ Qanun Number 11 Year 2014 Article 17 paragraph 1 point "d", states: implementing formal education financing and non-formal education for education units administered by the Aceh Government. 
occurred with Qanun Number 9 the Year 2015, the condition of madrasas have not changed, both in funding, curriculum, human resources, and infrastructure. The Aceh government still maintains madrasas as schools in all four elements. Although there was a change in the change of Qanun, it did not affect the position of a madrasa in Aceh. The problem then, how to implement the policy? Is it still the Aceh government taking sides in education in madrasas?

According to information submitted by the Aceh Education Office that Madrasah Aliyah is the same as other madrassas in a central authority. In determining special autonomy, Madrasah Aliyah is still a vertical institution which is not decentralized. His position is the same as the Police, Attorney General's Office, and other vertical institutions. Therefore, in funding, madrasas cannot be compared to schools in routine budgeting. Madrasa funding is only in the form of grants, and the provisions of the grant can be done if it is sufficient for the school's needs. ${ }^{52}$ The same information was also stated by the DPRA Members of Commission V in Education that madrasa funding cannot be equated with schools because madrasa rules are vertically different from schools, which are the responsibility of regional governments. Therefore, one way that can be done is through grants. ${ }^{53}$

The information shows that the position of Madrasah Aliyah in Aceh in the reform era is still marginalized. Equality previously recognized in Law No. 20 of 2003 and various Aceh regulations do not fit into reality. Local governments are still constrained by regulations in allocating the budget for Madrasah Aliyah in Aceh. Related to the existence of Madrasah Aliyah, which receives local government funding, even regularly, it is not purely a policy as a form of attention to education, but rather the relationship and ability of madrasas to "lobby" local governments. As stated by Mr. Saifullah: the local government wants to allocate funding for Madrasah Aliyah but it must go through a long mechanism and the madrasa must strengthen relations and the Aceh government. ${ }^{54}$

The implementation of policies in the curriculum has seen steps towards the application of policies. There are two forms of implementation, namely: First, requiring local content in the curriculum of all educational institutions in Aceh. This effort has seen a lot of progress, all schools/madrasas in Aceh have implemented such, but for certain sections adapted to local needs. Second is the formulation of an Islamic Aceh curriculum. This curriculum change is still in the process of being compiled. As stated by Darwis Sulaiman that the Islamic curriculum is being compiled. This curriculum is a priority for 2016-2017, and 2019 is

${ }^{52}$ Khaidir, Head of the Aceh Provincial Education Office Program Development Section, interview in Banda Aceh, January 9, 2017.

${ }_{53}$ Muhammad Alfattah, Member of DPRA Commission V for Education, interview in Banda Aceh, January 10, 2017.

${ }^{54}$ Saipullah, The Head of Mapenda, Aceh Provincial Office of the Ministry of Religion, interview in Banda Aceh, January 10, 2017. 
expected to produce an Islamic curriculum that is Islamic. ${ }^{55}$ There are three elements to become part of the Aceh curriculum, namely Islamic religious education, general knowledge (Indonesian or national curriculum), and local content. ${ }^{56}$

This local content is related to three. First is the history of Aceh. The history of Aceh in the Aceh curriculum is taught in a separate section. In contrast to the history studied now includes social studies. If in the Aceh curriculum, the history of Aceh is studied independently starting from the time of entering Islam to Aceh. Second is Aceh Culture. The part that is included in Aceh culture is art and culture, including traditional arts and languages. The third is the craft. In this case, what is taught is workshops and so on. Local content materials will be further developed, for example, learning languages not only Acehnese languages but also other local languages or foreign languages, as well as crafts, which are taught are various crafts from various regions in Aceh and Indonesia.

The implementation of the policy on human resources was carried out by the Aceh government in the form of equitable distribution of human resources, namely assigning teachers of teaching and education services to Madrasah Aliyah, and improving the quality of teachers. The local government assigned several teachers to help the teaching and learning process in Madrasah Aliyah. This effort has been carried out by the Aceh government through the Office of Education assigning 400 teachers to teach at Madrasah Aliyah with payment of salaries by the Office of Education. ${ }^{57}$

As MAS Darul Mukhlisin Takengon received the help of general subject teachers from the Education Office because the available teachers were inadequate, and the available teachers were also outside the area of expertise. Likewise, the Iyu River MAS got the help of an English teacher. MAN Lhoksukon got 4 teachers from the education department in general subjects. The Banda Aceh Model MAN also received 5 teachers assigned to the education service in general subjects. From the description of the data, it can be seen that the implementation of policies on human resources has been well established between madrasas and the education office.

Judging from the description of the implementation of the policy has not shown equality between madrasas and schools. In funding, there is no financial balance between Madrasah Aliyah and schools. Likewise, the facilities and infrastructure have not been seen evenly. The equalization of Madrasah Aliyah with other vertical institutions will only make Madrasas far from the education system in Aceh. Also, the allocation of grant assistance

${ }^{55}$ Darwis Sulaiman, Chairperson of the Aceh Regional Education Council (MPD) Curriculum Commission and the head of the Aceh Islamic curriculum preparation team, Interview in Banda Aceh, January 12, 2017.

${ }^{56}$ Sulaiman, Chairperson of the Aceh Regional Education Council (MPD) Curriculum Commission, Interview in Banda Aceh, January 12, 2017.

${ }^{57}$ Khaidir, Head of the Aceh Provincial Education Office Program Development Section, interview in Banda Aceh, January 9, 2017. 
by local governments has not been proportional. Local governments prioritize the system of "lobbying" and political relations rather than paying attention to the education system.

From the aspect of human resources, it appears that the government has begun to pay attention to the shortage of teachers in madrasas as evidenced by assigning teachers within the Department of Education to teach in Madrasah Aliyah. But that is not all agreed by the Education Office, there are still madrassas who lack teachers and have tried to ask for help from the Regional Government but were unsuccessful. The case of Madrasah Aliyah Negeri 1 Meulaboh has 30 people or $50 \%$ of the needs. So, the MAN needs 30 more teachers to cover previous deficiencies. These efforts have been carried out by asking for assistance from the Education Office, but there is no answer yet. To cover the lack of teachers, the madrasas finally received honorarium/service teachers with salaries paid according to the ability of the committee in the madrasas. The case of MAN 1 Meulaboh should not have happened, especially since the madrasa is considered superior and organizes homeschooling learning processes for its students. Not to mention the case in other madrassas that ask teachers for help from the Education Office, but the amount sent does not match the amount requested. MAS Darul Mukhlisin asked 6 teachers only 1 person to be filled, after that, never given again.

The problem is, why does the Aceh government marginalize madrasas, even though in madrasah regulations they are equivalent to schools? Responding to this problem, the regional government put forward two reasons. First is central regulation. The results of interviews with the Education Officer and the DPRA Commission V, in general, all agreed to help madrasas together with schools. But the rules and regulations that limit these desires, violating the rules mean ready to accept the consequences. ${ }^{58}$

Also, the budget allocation system for education, both from the APBA and the revenue sharing of oil and gas, has been bound by certain priorities, especially the salary of employees who dominate from all budgets for education. During this time, there was an error in understanding 20\% for education funding. Funds of 20\% from APBA by the Aceh government are allocated to 14Dinas. Then in 2016, the fund was devoted to only four, namely the Education Office, the Dayah Board, the Regional Education Council, and the human resource improvement agency (LPSDM).

\section{The Impact of Government Policies on the Implementation of Madrasah Aliyah in Aceh}

Seeing the policies and implementation of madrassas in Aceh will certainly have a negative impact on the administration of madrasas. Institutionally, the administration

${ }^{58}$ Khaidir, Head of the Aceh Provincial Education Office Program Development Section, interview in Banda Aceh, January 9, 2017. 
of Madrasah Aliyah is marginalized. In many cases, madrasas are not given much attention to local governments. Related to budget allocation, madrasas are different from schools. Schools do routine budgeting, while madrasas go through the grant channel. The problem is not only in the clustering of funding channels, but the determination of the right to receive techniques, madrassas are also marginalized. It is not enough for Madrasah Aliyah to only detail the needs by showing its shortcomings, but loyalty is preferred. Like family, friends, or other emotional relationships. This was as informed by the Head of MAN Seumeulu that he had to meet with the Regional Secretariat several times so that the budgeted funding was not removed. ${ }^{59}$

Also, sub-production. Institutionally Madrasah Aliyah is always under the school. Education in schools is more complete with facilities; teachers meet the needs and knowledge, adequate infrastructure. Unlike the madrasa, even though it has become superior, there are still many shortcomings that are seen in the implementation. For example, the Banda Aceh Model MAN had to add 12 honorarium teachers to handle 28 study groups. Likewise in funding, schools have sufficient funds from the local government, in contrast to Madrasah Aliyah, often the funds allocated are insufficient.

In addition to the impact of madrasah and subordination to madrasas, another impact is the apathy of Madrasah Aliyah towards the Aceh government. Madrasah Aliyah feels that it is not part of the education system in Aceh and even acts indifferent and indifferent to local government policies. For Madrasah Aliyah, whatever the local government does, they can't get their share. For example, MAN Lhoksukon claimed to have been often ignored by local governments. Likewise, the Bayu Private Madrasah Aliyah has repeatedly asked for assistance from the local government, but it has never been fulfilled. The attitude shown by the local government has a boring effect on madrasas to expect assistance from the regional government.

\section{Conclusion}

Based on the above study, it was found that the condition of Madrasah Aliyah in Aceh was still lacking, both in terms of funding, curriculum, human resources, and infrastructure. However, in terms of regulation the position of madrasas is equivalent to schools, both in Law Number 20 the Year 2003, the Aceh Education Qanun, and the education strategic plan. However, in implementation, the rules in favor of the madrasa are not in accordance with the realization. The position of madrasah is still marginalized in the education system in Aceh.

Whereas the 1945 Constitution (Amendments) commonly called the 1945 Constitution

59 The head master of Madrasah Aliyah Negeri Seumeulu, interview in Seumeulu City, Januari 17, 2017. 
of the Republic of Indonesia regulates decentralization and regional government units in Indonesia that is, besides adopting an asymmetrical (uniform) decentralization model and recognizing asymmetrical (diverse) decentralization. Arrangements regarding asymmetric decentralization are found in Article 18A paragraph (1), Article 18B paragraph (1) and (2) and Law. No 44 of 1999 as well as the Law. No. 11 of 2006 stated that Aceh has specificity and privileges compared to other provinces. Aceh was also given the authority to run the entire public sector except for five aspects namely foreign policy, defense, security, justice, monetary and national fiscal, and religion. Madrasa is one of the educational institutions under the Ministry of Religion that is disputed, whether it is centralized or not. On that basis, the Province of Aceh needs special attention based on the legal principle of lex specialis derogat legi generalis.

\section{References}

Ahid, Nur. "Problem Pengelolaan Madrasah Aliyah dan Solusinya," in Islamica, Vol. 4, No. 2, 2010.

Arifin, Anwar. Memahami Paradigma Baru Pendidikan Nasional dalam Undang-Undang Sisdiknas. Jakarta: Dirjen Kelembagaan Pendidikan Islam Departemen Agama RI, 2003.

Badan Standar Nasional Pendidikan. Peraturan Menteri Pendidikan Nasional Republik Indonesia Nomor 41 Tahun 2007 tentang Standar Proses Untuk Satuan Pendidikan Dasar Menengah. Jakarta: BNSP, 2007.

Basrowi \& Suwandi. Memahami Penelitian Kualitatif. Jakarta: Rineka Cipta, 2008.

Creswell, John W. Desain Penelitian, Pendekatan Kualitatif, tr. Angkatan III\&IV KIK-UINur Khabibah. Jakarta: KIK Press, 2002.

Gunawan, Heri. Kurikulum dan Pembelajaran Pendidikan Agama Islam. Bandung: Alfabeta, 2013.

Imron, Ali. "Penguatan Islam Moderat Melalui Metode Pembelajaran Demokrasi di Madrasah Ibtidaiyah", in Jurnal Edukasia Islamika; Jurnal Pendidikan Islam, Vol. 3 No. 1, 2018.

Milles, Mattew B. \& A. Michael Huberman. "Manajememen Data dan Metode Analisis", in Norman K. Denzim dan Yvonna S. Lincoln, Handbook of Qualitative Research, terj. Dariyanto, et. al. Jogyakarta: Pustaka Pelajar, 2009.

Moleong, Lexy J. Metodologi Penelitian Kualitatif. Bandung: Remaja Rosdakarya, 2012.

Pratama, Yoga Anjas. "Integrasi Pendidikan Madrasah dalam Sistem Pendidikan Nasional: Studi kebijakan Pendidikan Madrasah di Indonesia," in Al-Tadzkiyyah: Jurnal Pendidikan Islam, Vol. 10 No. 1, 2019.

Siregar, Imam et.al. Problematika Madrasah Era Otonomi Khusus. Jakarta: Litbang dan Diklat Departemen Agama RI, 2007. 
MIQOT Vol. 44 No. 1 January-June 2020

Stufflebian, Daniel L., et al. Evaluation Models Viewpoints on Educational and Human Service Evaluation. London: Kluwer Academic Publishers, 2000.

Sulaiman, Darwis A. et al. (ed.). Rencana Strategis (Renstra) Pendidikan Naggroe Aceh Darussalam 2007-2012 Banda Aceh: Guruminda, 2007.

Suparlan, Parsudi. Pengantar Metodologi Penelitian Kualitatif. Semarang: Fakultas Tarbiyah, 1993.

Tan, Charlene. "Contesting Reform: Bernstein's Pedagogic Device and Madrasah Education in Singapore," in Journal of Curriculum Studies, Vol. 42, No. 2, 2010.

Tilaar, H.A.R. \& Riant Nugroho. Kebijakan Pendidikan: Pengantar untuk Memahami Kebijakan Pendidikan dan Kebijakan Pendidikan sebagai Kebijakan Publik. Yogyakarta: Pustaka Pelajar, 2009.

Tilaar, H.A.R. Paradigma Baru Pendidikan Nasional. Jakarta: Rineka Cipta, 2004.

Warsito, Hermawan. Pengantar Metodelogi Penelitian Jakarta: Gramedia Pustaka Utama, 1995.

Werner, Jann \& Kai Wegrich. Handbook of Public Policy Analisys: Theory, Politic, and Methods. New York: CRC Press Taylor And Francis Group, 2007.

Yahya, M. Daud. "Posisi Madrasah dalam Sistem Pendidikan Nasional di Era Reformasi," in Jurnal Khazanah, Vol. XII, No. 01, 2014. 